\title{
Fostering Students' Creativity Through Modelling as Teaching-Learning Process to Write Poetry for International Students in University Level
}

\author{
Prima V. Asteria ${ }^{1, *}$ Arik Susanti ${ }^{1}$ Respati R. Utami ${ }^{2}$ \\ ${ }^{1,2}$ Universitas Negeri Surabaya \\ *Corresponding author. Email: primaasteria@unesa.ac.id
}

\begin{abstract}
This research aims to describe how modelling was implemented in learning writing poetry for international students. The teacher took several steps to increase students' creativity in writing poetry, namely; 1) Prewriting/ modeling 2) Arrangement/ Brainstorming 3) Drafting/ Creating Poetry, and 4) Revising. The research design was qualitative method that interprets phenomena seen from the side of the meaning. The participants were nineteen international students who were studying Indonesian at one public university in Surabaya, East Java, Indonesia. The instruments were an observation sheet, journal logs, and interview protocols. The results revealed in fostering students creativity to learn writing a poetry, some steps were implemented. Therefore, the lecturer had played an essential role to carry out in learning to write poetry. Problems faced by students when they were learning writing poetry were limited time to study and vocabulary knowledge. To sum up, modelling is one method to develop students' creativity for international students who have learnt Indonesia language. Providing authentic materials could also help students to explore their ideas and overcome vocabulary knowledge. It is recommended to implement another method integrated to technology to improve students' creativity.
\end{abstract}

Keywords: Write poetry, Modelling strategy, Creativity

\section{INTRODUCTION}

Recently, creativity has played a vital role in educational, humanities, arts, and social and behavioral sciences. Creativity has become one of the most critical issues of organizations and enterprises due to its involvement in innovation and entrepreneurship [1]. Creativity is the ability to generate new ideas that are both startling and understandable, as well as helpful in some way [2]. The students' creative aspects are reflected in the texts that they write in the classroom. The teacher must encourage her students to write their ideas by drawing upon their imagination to develop students' creativity. It is one way to support their creative development. Moreover, it can be used fictional narrative as teaching and learning materials such as novels or poetry.

Learning poetry is one way that the teacher implements to develop students' creative skills, especially for an international school in Indonesia's language study program.
Poetry is a language essay short, dense, beautiful, and touching. The shape is arranged arrays and stanzas that contains rhythm and poetry with emphasis on feelings. The goal of writing poetry is to make students can preserve the language and literature of Indonesia. Moreover, writing poetry is a part of the learning literature that cultivates students' sentiment and reasoning on literature. Next, the students can practice their knowledge of how to write poetry. They do not only memorize their knowledge but also apply them in real life. Thus, they cannot easily forget their knowledge.

Developing students' creative skills in learning to write poetry can be done through modeling strategies. Modeling is a crucial process in teaching and learning to write poetry. When the teacher applies modeling as a teaching-learning process, it can bridge between the learners' capacity to interpret facts and the multiple aspects of these facts that substantially work by representing hidden semantic connections and organizing them in a comprehensive meaning. Moreover, modeling is a flexible way to understand students' knowledge constructions to master their own experiences. They 
provide organized support guiding their interpretation of a complex phenomenon, creating the possibility of attaining the comprehension of new phenomenologies.

It could also promote students' creative skills when they write poetry. Creativity can be seen in students' written works in poetry, which contains ideas formed in a paper with meaning. When students have creative skills, they can create something new, whether it be the idea or act in the actual work, either it's the things that already exist or have never existed before.

Creative thinking is critical to be developed. It could make students become useful for themselves and others. Hence, there are some preparation, challenges, and obstacles to help students be creative learners. Creative learning allows students to solve problems and orient themselves even though we are not with them. Creativity is an individual mental process that gives birth to ideas, techniques, methods, or new imaginative, aesthetic, flexible, integration, succession, discontinuity, and valuable differentiation in various fields for solving a problem [3]. When students have creative skills, students can manage information, do something and make something or create a product that can be interpreted by the individual [4].

The teacher can assess some aspects to decide whether her students are creative learners or not, such as fluency thinking skills, flexible thinking skills, original thinking skills, and elaboration skills. Some studies showed that poetry in learning English could foster students' creativity skills, especially in supporting Japanese students' English skills. Most of them can use and apply the language expressions in poetry. The students can develop their English skills and creativity through writing poetry [5]. In addition, the use of a variety of mixed media can increase students' creativity in writing poetry.

To fill the research gap, this study would focus on using modeling as a teaching-learning process to write poetry to foster international students' creativity. It shows that there are still few studies examining the use of formula strategies to foster creativity. The study's objective was to describe the implementation of modeling as a teaching-learning process to write poetry.

\section{METHODS}

This study was a qualitative research that included an interpretive and naturalistic approach to the subject. It interprets phenomena seen from the side of the meaning that humans attach to them [6]. The participants were 19 foreign students who were studying Indonesian at a public university in Surabaya, East Java, Indonesia. The instruments were an observation sheet, journal logs and interview protocols to describe how modelling was implemented in learning to write poetry. There were some steps to collect the data. First, the researcher observed how the process of teaching poetry using modelling in writing poetry to promote students' creativity. Next, interviews with teachers and students were also carried out to explain something that was not or has not been caught using observation sheets [7].

The data obtained in this study were pieces of information found in the learning process consisting of direct quotes from interviews or detailed descriptions of behavioral activities recorded in observations [8]. Data collection techniques used in a study are determined by the theoretical orientation of the researcher, by the problem and research objectives of the study, and by the sample selected. In this study,

The data analysis technique was carried out in three stages; namely, 1) impartial means not discussing the data that has been collected based on opinions or things that the researcher likes only. 2) honest in research to provide results based on an objective point of view. Researchers must report all findings even if they conflict with the theme. 3) research must protect the privacy of sources. This is by separating names of responses during the coding or recording process. This is intended to protect the identity of participants [7].

\section{RESULTS AND DISCUSSION}

The teacher took some steps to increase creativity in making poetry that are divided into four stages, namely; 1) Prewriting/ modeling 2) Arrangement/ Brainstorming 3) Drafting/ Creating Poetry 4) Revising. These four stages are essential to provoke knowledge, curiosity, and imagination about specific topics that have been determined by the teacher so that, in the end, students can write poetry. In the early stages of poetry creation, they imitate the modeling shown by the teacher. However, the creative process of students grows when they can create original poetry and have different characteristics. Creativity is the act of generating fresh thoughts, methods, or activities, as long as innovation is a new way to consider and vary it [9].

\subsection{Pre Writing/Modelling}

At this stage, the teacher gives two examples of poetry texts entitled "I want." This poem expresses people's feelings and desires. Both of these poems use the word "I want," but they describe different situations. These two poems also show distinct feelings. In learning to write poetry aimed at BIPA students (international students studying Indonesian), the teacher must show poetry models that can provoke ideas in making each student's version of poetry. The text of the poem used is: 


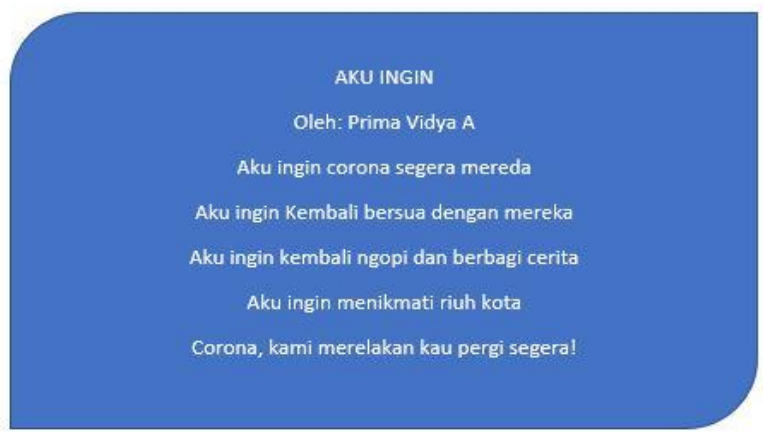

Figure 1 Example of first poetry text

The text of this first poem shows anxiety about the Covid-19 pandemic that has hit the world. The author wants Corona to disappear from the earth to meet up and gather with his friends and family without any restrictions. He could enjoy the view of the bustling city. Many people are selling, buying food, even just taking pictures with loved ones. The author hopes that Corona will go away soon.

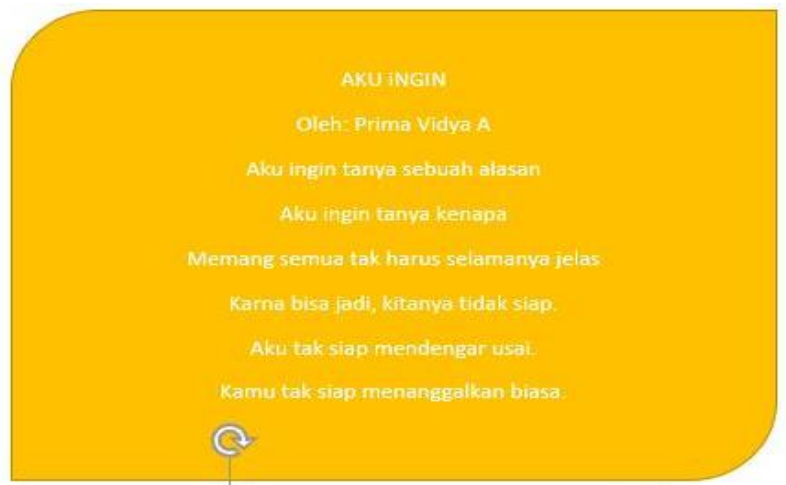

Figure 2 Example of second poetry text

This second text is about a dilemma experienced by the author. He is in a romantic relationship with someone, but the relationship starts to have problems. He wanted to clarify his relationship by asking his partner. He wanted to ask what caused his lover to change, but he was afraid. $\mathrm{He}$ is worried that his lover has another woman, and he is fearful that his lover will no longer love him. But the dilemma is not only felt by him alone. His lover also felt the same way. He was afraid to say goodbye because he was used to being together. The feeling of getting used to it will leave scars even though love has faded.

The poem's two different situations and conditions show that the same word, namely "aku ingin" can be translated variously by students depending on the ideas and facts they choose to make a poem. Based on the explanation from the teacher regarding the definition, types, characteristics, structure, and ways of making poetry, students will get an idea of how to make poetry in Indonesian. They can associate one word with another to add an element of beauty to the poem.

\subsection{Aransemen/ Brainstroming}

Brainstorming is a method for generating ideas, determining solutions, and expressing fresh thoughts. The primary purpose of brainstorming is to create as many solutions as possible to solve the problem at hand [10]. Students do brainstorming by looking for data related to the topic raised. Then, they would look for the correct vocabulary to represent the feelings and write poetry. After that, include elements of beauty, connotation, and figure of speech to make the poem more meaningful. The teacher gives the steps to help BIPA students find ideas for making poetry are four described in the table below.

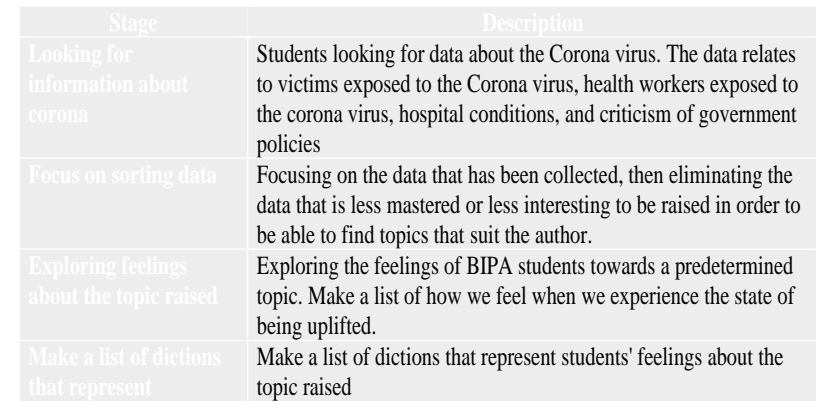

Figure 3 Brainstorming steps

The role of the lecturer is significant in this brainstorming stage. BIPA students are international students who study Indonesian online. They must have had a hard time expressing ideas about Corona and then realizing it in the form of poetry. The limited Indonesian vocabulary has resulted in the poetry produced having a low level of creativity. Therefore, teachers must help provide an overview of the number of Indonesian people exposed to the Coronavirus. This is due to the government's less optimal handling of the Covid pandemic. And the problem is that the number of hospitals and health workers is not comparable to patients with Corona, so many people die before they can be treated properly. The problems faced when Corona attacked Indonesia could inspire BIPA students to write poetry about Corona from different perspectives.

Focus is the key to being able to sort out the most collected data. This level of mastery is related to the amount of data and the knowledge of vocabulary related to the topic raised. In addition, it also needs a deep feeling about the issue raised so that the written poetry can represent the reader's feelings. The list of dictions made will facilitate the stages of making poetry.

\subsection{Drafting/ Creating Poetry}

Creative is usually paired with thinking, which means cognitive operations that deal with "individuals who are creative, free, spontaneous, and unpredictable, and are used to set norms, goals, and expected outcomes [11]." At the same time, Weldo said that creative writing is an 
activity to create imaginative and informative texts that show the use of appropriate text structure, word choice, punctuation, and appropriate forming elements [12]. Poetry writing is a form of creative writing. Through writing poetry, students can learn about imaginative literary works but use diction that has a figurative meaning.

The development of writing skills can increase creativity and provide a strong stimulus for selfexpression [13]. This activity aims to facilitate students' social skills and literacy and offers media to explore social, political, health, and environmental problems in Indonesia so that the resolution of the Corona problem in Indonesia seems slow. Learning to write can have a longterm effect on students to hone empathy and concern for fellow human beings. Ostrom says that creative writing activities create knowledge because writing activities can teach students about life and personal experience as a form of self-expression [14].

In writing poetry, it is necessary to connect fiction with the events experienced by the author. The disclosure of these events requires a symbolic or semiotic style of language. Symbolic is a fixed and cohesive illusion, whereas semiotic is a form of opposition. The semiotic throws into confusion all tight divisions between masculine and feminine and offers to deconstruct all the moral binary oppositions, proper/improper, norm/deviation, sane/mad, mine/yours, authority/obedience, by which societies such as ours survive [15]. Symbolic and semiotic language styles help to express oneself and critique an event raised in poetry. The language style is also an element that is difficult to apply in BIPA students' poetry, and this is because the vocabulary they know is minimal. They have difficulty understanding the use of one word, but a particular figure of speech symbolizes it. For example, the mention of a child who likes to learn is a "kutu buku" bookworm. The statement of the silver spoon "sendok perak" for the underlings. The mention of "kaset rusak" crumpled tapes shows how bad the voice of someone is being satirized. These connotative words are difficult for BIPA students to understand. Therefore, the material about language style needs to be explained in depth so that they know.

\section{CORONA ITU...}

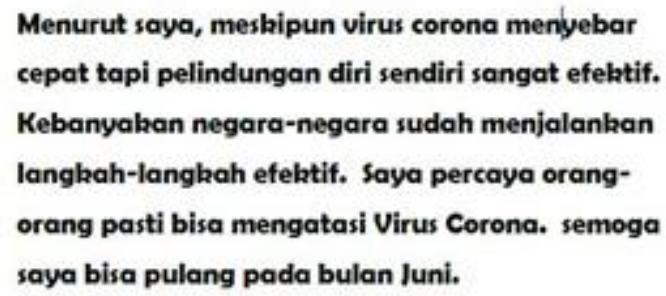

\section{Zunaira - China}

Figure 4 Example of a poem about Corona by international students

The poem made by Zunaira, a student from China, is very dry. He couldn't understand the structure of poetry yet. He does not use semiotic language or symbols to describe the spread of the Coronavirus, the handling of covid, and his hopes. He only wrote a short sentence about Corona. He does not include his experience away from family during Corona; he does not use dictions that describe the anxiety and sadness that his family in China is facing. He does not express critical or creative things in his writings. It shows that creative writing requires commitment and high curiosity to be able to create exciting poetry.

\subsection{Revising}

The revision stage is the stage of providing feedback and evaluation from the lecturer to improve the writing skills of BIPA students. Writing poetry in a foreign language is undoubtedly not an easy activity. Therefore, lecturers must provide input and direction to students to revise according to the proper poetry structure.

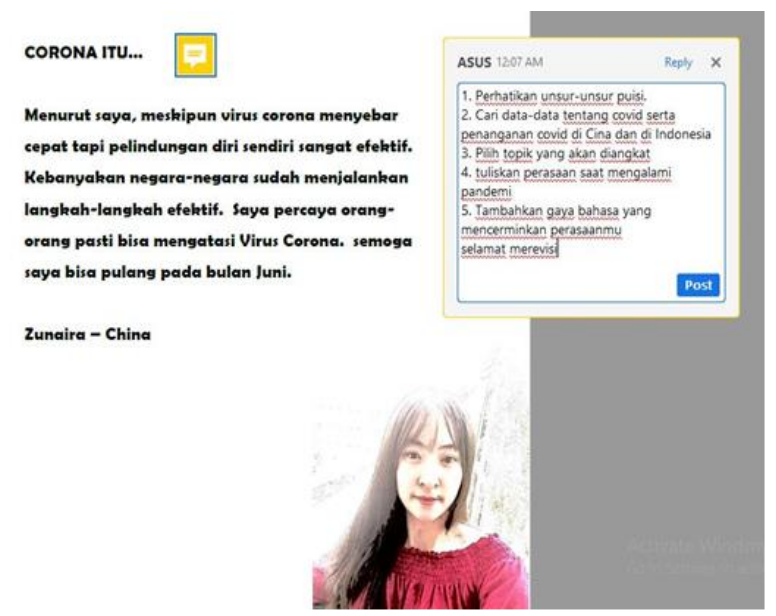

Figure 5 Feedback on writing activities

Feedback is given by making notes about mistakes and errors that students must correct. After that, the lecturer must ask for the results of the student's revision 
so that changes in writing abilities can be seen for the better. Learning to write using the Modelling strategy carried out on BIPA students requires the lecturer's prominent role and intervention. Moreover, learning is done online; this is very difficult for students who cannot speak Indonesian fluently. But the task of making poetry will be fun because of a high commitment. Students must conduct in-depth research, look for references to diction and figure of speech that are often used in Indonesian literary works, and include elements of the author's personal feelings in the appointments made.

\section{CONCLUSION}

This study exposed that there are four stages, namely; 1) prewriting/ modelling, 2) arrangement/ brainstorming, 3) drafting/ creating poetry, and 4) revising for learning writing poetry. To foster students creativity, the lecturer uses modelling to write poetry. Therefore, the teacher has provided authentic material that help students to get some ideas. However, it is limited time and vocabulary knowledge, some students get difficulty to write poetry. It is recommended to use many kinds of model integrated to technology to promote students' creativity.

\section{REFERENCES}

[1] Ş. T. and A. Kandemir, "Effects of Creative Writing Activities on Students' Achievement in Writing, Writing Dispositions and Attitude to English," Procedia - Soc. Behav. Sci, vol. 174, pp. 1635-1642, 2015, doi: doi: 10.1016/j.sbspro.2015.01.815.

[2] C. Lassig, "A typology of student creativity: Creative personal expression, boundary pushing and task achievement," Think. Ski. Creat, vol. 36, 2020, doi: doi: 10.1016/j.tsc.2020.100654.

[3] J. C. Richards, "Creativity in language teaching," Iran. J. Lang. Teach. Res., vol. 1, no. 3, pp. 19-43, 2013, doi: 10.4324/9781315730936-8.

[4] I. Setyowati, E., Kristin, F. and Anugraheni, "Penggunaan Model Pembelajaran Discovery Learning Untuk Meningkatkan Kreativitas Dan Hasil Belajar Siswa Kelas 5 Sd Negeri Mangunsari 07,” J. Sains dan Teknol., vol. 1, no. 1, p. 76, 2018.

[5] N. Rosenhan, C. and Galloway, "Creativity, self-re flection and subversion: Poetry writing for Global Englishes awareness raising," System, vol. 84, pp. 113, 2019, doi: doi: 10.1016/j.system.2019.04.005.

[6] Y. S. L. Norman K. Denzin, Handbook of Qualitative Research, I. Yogyakarta: Pustaka Pelajar, 2017.

[7] J. D. Creswell, W. J. and Creswell, Research Design: Qualitative, Quantitative and Mixed Methods Approaches, Journal of Chemical Information and
Modelin. 2018.

[8] M. Q. Patton, Qualitative research and evaluation methods (4th ed.). Central Avenue: SAGE Publications Inc., 2015.

[9] S. P. Chitra, "Creativity and innovation: A business practice to realize the concept of make in India," Intern. J. Busin. Manag., vol. 2, pp. 702-714, 2015.

[10]D. Toft, The essential guide to becoming a master student, 2nd Ed. Wadsworth: Cengage Learning, 2012.

[11] J. Cook, Creative writing and Ph.D. research. In H. Beck (Ed.), Teaching creative writing. London: Palgrave Macmillan, 2012.

[12]F. Weldon, "Fay Weldon speaks up for creative writing," Times High. Educ., 2013, [Online]. Available:

http://www.timeshighereducation.co.uk/comment/o pinion/fay-weldon-speaks-up-forcreative\%0Awriting/2003556.article\%0A.

[13]D. Appleman, "Teaching in the dark: the promise and pedagogy of creative writing in prison," English J., vol. 102, no. 4, pp. 24-30, 2013. [Online]. Available:

http://www.ncte.org/library/NCTEFiles/Resources/J ournals/EJ/1024\%0Amar2013/EJ1024Teaching.pdf\%0A.

[14]H. Ostrom, "Hidden purposes of undergraduate creative writing: Power, elf and knowledge. In $\mathrm{H}$ Beck (Ed.)," Teach. Creat. Writ., vol. 12, no. 2, pp. 80-85, 2012, doi: http://dx.doi.org/10.1057/9781137284464.0016.

[15] T. Eagleton, Literary theory (2nd Ed.). Cambridge: Blackwell, 1996. 